\title{
L1 Use in L2: Should We Omit It? Reexamining the L2- Only Policy in Foreign Language Classroom
}

\author{
${ }^{* 1}$ Anisatul Maghfiroh , ${ }^{2}$ Ahmad Choirul Anwar \\ ${ }^{* 1}$ SMPN 6 Pekalongan, Indonesia, Email: anisatul.mb@gmail.com \\ ${ }^{2}$ Universitas Muhammadiyah Malang, Indonesia, Email: anwarahmad179@ gmail.com
}

Submitted: 13/09/2019 Revised: 14/10/2019 Accepted: 20/11/2019

How to cite this article: Maghfiroh, A., \& Anwar, A.C. (2019). L1 use in L2: Should we omit it? Reexamining the L2-only policy in foreign language classroom. IJELR: International Journal of Education, Language, and Religion, 1(1), 26-31. http://doi.org/10.35308/ijelr.v1i1.1754

\begin{abstract}
The use of L2-only policy in foreign language classroom has been debated in academia. Questions around the debate revolve around; will it really be very effective and fruitful as well as comfortable for both the students and teachers of foreign language classes to use only L2 and completely omit L1 in their classroom activities? If not, how much should we limit the use of L1 in order to create a comprehensive language acquisition in class? The objective of this paper is to map the discussion about some supporting and opposing arguments on L2-only policy in foreign language classroom. Studies suggest that even though there are some opinions that L1 equals to comfort zone, we argue that there will not be any advantages to put the students in their anxiety when learning new language. Instead, students will feel uneasy and will result in their lack of motivation.
\end{abstract}

\section{Keywords}

L1; L2; foreign language; language policy; language teaching

\section{Introduction}

One of the most debatable topics in the field of foreign language teaching is the use of target language (L2) and the reduce of native language (L1). Many researchers argue that target language- only classroom is the most ideal in order to enhance students' acquisition in foreign language. Hlas (2016) stated "there is little doubt that maximizing the quantity and quality of language (TL) is the primary goal of foreign language teachers". She also added the statement made by Council of Chief State School Officers $(2002 ; 20)$ which proposed that it is important for language teachers to understand that consistent and comprehensible amount of input in target language during the learning time in class is "fundamental" to the foreign language learning process. In addition, several researchers have claimed the maximum use of L2 will give positive improvement to the learners' acquisition as there are more exposure of L2. However, some question then aroused; Is there really no place for L1 use in language classroom? Will it really be very effective and fruitful as well as comfortable for both the students and teachers of foreign language classes to use only L2 and completely omit L1 in their classroom activities? If not, how much should we limit the use of L1 in order to create a comprehensive language acquisition in class? 
In contrast to the strict belief and suggestion to omit L1 completely from foreign language teaching, several researchers conducted studies that proved the positive influence of using L1 in L2 acquisition. Chiou made a quote to Nation (2003) about the positive use of L1 in foreign language classes. Nation argued that despite of its hindrance in a full exposure of L2, using L1 in foreign language classes activity can create a friendly and comfortable atmosphere. Supplementary use of L1 also offers a familiar and effective way for the learners to be more engaged to the learning materials, which will save time and keep the learner motivated, especially for limited English proficiency learners. Mole (2009) also suggests that "the exclusive use of English in ESL class should be workable but the use of L1 should be more efficient and more successful, which might probably refer to the effectiveness of code- switching to L1 when the teachers are explaining about certain complex concept or grammatical rules of L2. In addition, Dong (2013) believes that utilizing L1 in L2 classroom can help the students to understand content as well as motivate them to learn more.

\section{Discussion}

\section{Opposing Arguments}

The issue of learners' L1 in L2 classroom has become a classical and one of the most important topics to discuss among language researchers and practitioners. The teachers are encouraged to reduce, if not completely omit, using L1 when teaching foreign language to their students. Thompson (2014) reveals that several studies done by previous researchers have proposed positive results that show correlations between the teacher's use of the target language and students' acquisition of the language.

In addition, Turnbull (2001) as quoted by Chiou (2014) believes that the consistent use of target language-only in classroom activities guarantee the quantity exposure to the target language that can lead to the successful learning and finally the better mastery of the target language. It is also proposed that teachers should completely exclude L1 use in class as it is considered to be a distraction for the students as Turnbull further claimed in his paper, "L1 should be completely excluded in the class and that there is no place for L1 in the class." This suggestion is also blatantly proposed by Council of Chief State School Officers $(2002 ; 20)$, which has been stated in the introduction of this paper, and further supported by American Council on the Teaching of Foreign Languages (ACTFL). As quoted by Hlas (2016), ACTFL specifically claimed their position on classroom language use. They stated that "language educators and their students use the target language as exclusively as possible $(90 \%$ plus) at all levels of instruction". Hals further quotes Turnbull (2001) who stated that maximizing the target language use in the classroom would yield some benefits as a way of providing input for learners and affect their proficiency in a positive manner.

In other study, Chiou (2014) also believes that using the maximum amount of L2 in the classroom means providing maximum input of the target language that the students need in foreign language. She furthers stated that "the best way to learn a new language is to be immersed in the target language." As she conducted her research in Taiwan, which has EFL context as a background, she claimed that the foreign language classroom can presumably be the only place where the students are exposed to the target language. Thus, teachers have to maximize it as their most resourceful input. In addition to this belief, Chiou quoted Phillipson (1992) that "if one wants to learn English well, the he must listen, speak, read, and write in English as often as possible"

In another approach, Pablo et al (2011) made a summary of the historic transition that can served as a rhetorical background of the gradual emittance of L1 use in language learning Quoting Lewis (2009) and Lindsay \& Knight (2006), Pablo et al describe how different teaching methods deal with the use of L1 in the classroom. They started with the Grammar Translation Methods (GTM), which was formally developed in $18^{\text {th }}$ century. With this method, teacher can just explain the L2 grammar in detail, and simply use translation to translate texts from L2 context to L1, they do not have to use L2 as the main goal was the mastery of grammatical rules. 
Moving on to the practice of language learning in the $20^{\text {th }}$ century, the introduction of Direct Methods (DM) proposed the idea of using only the target language in conducting the lesson. In this case, teachers have to start utilizing their competence in performing their L2 skills, not only explaining about them. The continuous variation and shifting from Direct Methods to Audio-Lingual (ALM) and Communicative Language Teaching (CLT) has gradually shove L1 from its original influence in GTM. CLT in particular, has shifted the focus of the meaningful process of language learning from just "learning about the language" to "communicating in the language". Furthermore, L1 is then viewed with phrases as "limited use" and "interference".

Another argument for L2- only instruction is the view that incorporating L1 in L2 classroom will somehow slow down the learners' acquisition of L2. Rolin-Ianzitu \& Varshney (2008) conducted a research that questions the students' perception of the use of L1 in their language classroom. The result indicates that the students favor the emittance of L1 in their L2 classroom to the minimum level as they think that it will hindrance their learning. Some students stated that L1 use may cause some drawbacks in their learning because it will make them to be too dependent to L1, when they have difficulty of understanding certain L2 terms, they will easily give up and switch to L1. Contrastingly, more exposure to L2 will benefit them in picking up phrases or L2 words from the context. Moreover, better exposure to L2 can foster the students' spontaneous use of L2 and pronunciation. Students believe that the excessive use of L1 does not allow them to comprehend the phonetic features of L2 completely.

In conclusion, as Rolin-Ianzitu \& Varshney (2008) claimed in their paper, excessive use of the L1 may lead to a cognitive dependence on L1, which, when it is combined with fewer exposure and attention to L2, is viewed as a hindrance to language learning. From these negative views on L1 use, it can be concluded that students place a positive view to exposure to the L2. Those exposures may allow students to learn 'naturally' from the context, helps the acquisition of pronunciation, and directs attention to the TL.

\section{Supporting Arguments}

Despite the fact that maximizing the use of L2 in Foreign language classroom is ideal and desirable, many researchers stated otherwise. Hals (2016), quoting Cook (2001) and Turnbull (2001) claimed that "the use of L1 in L2 classroom can also serve as a resource." This statement is relevant with other researchers' claims about the benefit of incorporating L1 into L2 classroom. Chiou (2014) summarized Cummins' (1979) threshold hypothesis in relation to the role of L1 in L2 acquisition. Cummins believes that one's achievement and comprehension in L2 acquisition "relies heavily on his mastery of his native language". This idea proposed that when someone is studying a new foreign language, he/ she will make a transfer or knowledge from his/ her native language in order to make a connection of linguistic comprehension.

Hals (2016) also cited Macaro's (2009) notion who stated that there is an "increasing possibility that banning the first language from the communicative second language may in fact be reducing the cognitive and metacognitive opportunities available to learners." Macaro's notion explain that there are some beneficial in terms of cognitive and metacognitive aspects that students can conclude from their L1, which may be applicable to their L2. Students will consciously or unconsciously make a comparison between the two languages, their L1 and L2, in order to better comprehend the linguistic rules of the L2. This conscious/ unconscious transfer process especially happens in adult learner's learning, in which the learner has realized the linguistic aspects of a language and possess metacognitive skills. August (2006) as summarized by Chiou (2014) explained that adult learners process information in a different way compared to children, with respect to learning and to read L2. He further added that adults make use of their knowledge the attained from their L1 and then transfer it to their L2.

In EFL context especially, in which the students and teachers have the same linguistic and cultural background, using L1 enables the teachers to make a connection between grammatical rules applied in 
their L1 and in L2 they are learning. In fact, studies show that the L1 are maximally used in grammar classes, regardless any level or proficiency. Regarding the connection between employment of L1 and students' level of proficiency, Pablo et al. (2001) proposed two of possible reasons that can affect the teachers' decision in using L1 in their L2 classroom are the students' level of proficiency and the institutional curriculum. They added that it may be a general consensus in the language learning community that more L1 is accepted at lower levels of proficiency. However, the use of L1 has to be gradually reduced according to the higher level of proficiency.

With regards to the cognitive and linguistic role of L1, the employment of L1 in L2 classroom also rely heavily on the teachers' decision and students' preference. Thus, many researchers believe that there has to be some concern and attention to these perspectives. Chiou (2014) summarize Cianflone (2009)'s study which concludes that both teachers and students seem to have preference in using L1 when it comes to explaining grammar rules, vocabulary items, and difficult concepts for general comprehension. The L1 can thus facilitate the learning process. Pablo et al (2011) also conducted a research about students and teachers' reasons for using the first language within the foreign language classroom. The foreign language classrooms studied here are French and English in Central Mexico.

The study reveals results from teachers' point of view and students' point of view. They suggest that in addition to the fact that all teachers participated in this research did indeed have positive attitude on using L1 in their classroom, there are many possible factors that trigger the teachers' decision to do so. Two of the most important factors (according to me, that I want to raise and relate to other arguments in this paper) are their view of "L1 as a pedagogical device for clarification" and the use of L1 to establish rapport or connect them to their students. Pablo et al further revealed that the participants stated that they often use L1 as a tool to explain aspects such as instructions, grammar, and unfamiliar vocabulary and expressions. They also utilize L1 as a tool to provide a comparative analysis of the languages while sometimes still conducting the lesson in L2. Thus, they do not necessarily use L1 as the instruction language but elicit it as a mean of comparison. This revelation proved the point of the cognitive and metacognitive use of L1 that I explained in the previous paragraph.

According to Pablo et al., another reason that the teachers use is to establish rapport, to create a connection to the students and establish an empathy between them. They use simple chit chat and joke in L1 in between the lesson to lower the students' anxiety and create an environment where the students can feel more relax and ease in studying the foreign language. This idea can presumably be connected to Rolin-Ianzitu \& Varshney (2008)'s results on their research in a similar topic. They concluded that the teachers' use of L1 can alleviate the classroom anxiety that the students might feel due to the L2 exclusivity as well as establish a positive relationship between the teachers and students. The students will feel at ease and not shy when they make mistakes as the teachers are welcoming them in using their L1. Thus, it will wipe away the students' fear in making mistakes.

Students' positive attitude towards the use of L1 will make them believe that they will have a resort of using L1 when they make mistakes. This will increase students' motivation in learning L2 instead of feeling insecure as they were afraid to make mistake and knowing that they did not have any resort to turn into.

\section{Conclusion}

There has been no doubt that the role of L1 in L2 classroom will always be explored in the future, and many findings will be revealed about its effectiveness or its hindrance. However, condemning that L1 use useless and it should be banned entirely from L2 classroom is not wise. As many research reveals that using L1 as a core of studying L2 comprehension may even be more beneficial especially for the students who have already develop metacognitive skills. The information that they gain from the linguistic rule of their L1 can be a steppingstone and device in comprehending the new linguistic rule in their L2. Thus, it will make them easier to acquire the grammatical rules. 
Even though there are some belief that L1 equals to comfort zone, we do not think that there is necessary intention to put the students in the opposite situation. There will not be any advantages to put the students in their anxiety when learning new language. Instead, students will feel uneasy and will result in their lack of motivation.

We stand to the idea that L1 is still needed in the teaching and learning of target language, especially in the EFL situation. In our opinion, based on our teaching and assisting experiences, the conscious use of L1 is specifically needed in all level of class, regardless the learners' ages. It will, in most cases, be essential to have a code switching from L2 to L1 in Grammar Translation Method- class. However, the L1 use will have to be limited in other type of classes which use communicative approach such as Communicative Language Teaching and Audio-Lingual Methods (Fariduddin \& Parlindungan, 2018). To sum up, we believe that omitting L1 will not be a perfect solution for learners' successful mastery of language as it is still needed to be used in some situation, of course, with fair proportion compared to $\mathrm{L} 2$.

\section{References}

Bateman, B. E. (2008). Student teachers' attitudes and beliefs about using the target language in the classroom. Foreign Language Annals, 41(1), 11-28.

Chiou, B. (2014). Rethinking the role of L1 in the EFL classroom. English Teaching \& Learning, 38(4), 53-78. doi:10.6330/ETL.2014.38.4.03

Cianflone, E. (2009). L1 use in english courses at university level. ESP World, 8(22), 1-6.

Cook, V. (2001). Using the first language in the classroom. Canadian Modern Language Review, 57(3), 402-23.

Cummins, J. (1979). Linguistic interdependence and the educational development of bilingual children. Review of Educational Research, 49(2), 222-251.

Fariduddin, M., \& Parlindungan, F. (2018). Comprehending narrative text: the effectiveness of cooperative integrated reading and composition (CIRC). Ethical Lingua: Journal of Language Teaching and Literature, 5(2), 139-148.

Forman, R. (2015). When EFL teachers perform L2 and L1 in the classroom, what happens to their sense of self? Tesl-Ej, 19(2)

Hlas, A. C. (2016). Secondary teachers' language usage: Beliefs and practices. Hispania, 99(2), 305319.

Lindsay, C., \& Knight, P. (2006). Learning and teaching english: A course for teachers

Macaro, E. (2009). Teacher use of codeswitching in the second language classroom: Exploring 'optimal'use. First Language use in Second and Foreign Language Learning, , 35-49.

Moore, P. J. (2013). An emergent perspective on the use of the first language in the english-as-aforeign-language classroom. Modern Language Journal, 97(1), 239-253.

Pablo, I. M., Lengeling, M. M., Zenil, B. R., Crawford, T., \& Goodwin, D. (2011). Students and teachers' reasons for using the first language within the foreign language classroom (french and english) in central Mexico/Razones de alumnos y maestros sobre el uso de la primera lengua en el salon de lenguas extranjeras (frances e ingles) en el centro de mexico. Revista PROFILE: Issues in Teachers' Professional Development, 13, 113+.

Rolin-Ianziti, J., \& Varshney, R. (2008). Students' views regarding the use of the first language: An exploratory study in a tertiary context maximising target language use. Canadian Modern Language Review/La Revue Canadienne Des Langues Vivantes, 65(2), 249-273.

Thompson, G. L., \& Harrison, K. (2014). Language use in the foreign language classroom. Foreign Language Annals, 47(2), 321-337.

Turnbull, M. (2001). There is a role for the L1 in second and foreign language teaching, but.... Canadian Modern Language Review, 57(4), 531-540. doi:10.3138/cmlr.57.4.531

Rolin-Ianziti, J., \& Varshney, R. (2008). Students' views regarding the use of the first language: An exploratory study in a tertiary context maximising target language use. Canadian Modern Language Review/La Revue Canadienne Des Langues Vivantes, 65(2), 249-273. 


\section{(c) (1) (2)}

